J. Kyushu Dent. Soc. 52 (5):613 623, 1998.

\title{
Utility of a New Caries Activity Test
}

\author{
Si-Zhen Shi \\ Department of Pediatric Dentistry (Chief: Prof. Si-Zhen Shi) \\ Dental School, Shanghai Tiedao University, Shanghai, China \\ Department of Oral Bacteriology (Director: Prof. Choji Uchiyama)
}

Kyushu Dental College, Kitakyushu, Japan

Key words: Caries activity test/Dental caries/Preschooling children/Caries prevalence

Accepted on August 25, 1998

\section{Introduction}

The detection of caries activity is greatly important in order to understand the susceptibility of the host to caries and further make an effective plan for prevention and treatment of caries according to the results detected ${ }^{1,2)}$. It is a cost-effective example to make a special program of the prevention and treatment of caries after screening and grouping the results detected and will strengthen the education of oral hygiene especially in kindergartens and primary schools ${ }^{3-7)}$.

There have been no very ideal methods for detection up to date and few studies in this field in China. The purpose of this study is to investigate a convincing, simple and inexpensive detecting method which is comparable to the methods well known in the world, and to enhance the efficiency in the prevention and treatment of caries on a large scale. The method was named as Shanghai Tiedao University Caries Activity Test (SCAT). Its usefulness was evaluated in terms of the relationship of the test results with caries status obtained from dental examination as well as the comparison with other two conventional caries activity tests.

\section{Materials and Methods}

I. Materials

1. SCAT reagent preparation of standard solution for colorimetry

The contents in $100 \mathrm{ml}$ SCAT reagent are shown in Table 1 . The reagent was adjusted to pH 6.10 with $10 \%$ lactic acid, and $1.5 \mathrm{ml}$ each was poured into tube and sterilized for use.

The standard solution for colorimetry containing bromocresol green $0.0015 \mathrm{~g}$ and bromocresol purple $0.003 \mathrm{~g}$ per $100 \mathrm{ml}$ was prepared by adjusting $\mathrm{pH}$ with $10 \%$ lactic acid and divided into four degrees: Degree 0, dark-blue, pH 6.10; Degree 1, green pH 5.40; Degree 2, yellow-green, pH 4.70; Degree 3, yellow, pH 4.00. The caries activities were expressed by these degrees according to the color changes. Degree 3 means the most caries risk condition.

2. Dentocult LB detection materials

The materials used were special paraffin for chewing, thin layer of selected medium 
specialized for lactobacillus and the standard map for measurement. The map was divided into four degrees according to the number of bacterial colonies: Degree $0,10^{3} \mathrm{CFU} / \mathrm{ml}$; Degree 1, $10^{4} \mathrm{CFU} / \mathrm{ml}$; Degree 2, $10^{5} \mathrm{CFU} / \mathrm{ml}$; Degree $3,10^{6} \mathrm{CFU} / \mathrm{ml}$. They were used to represent the caries activity. Degree 3 means the highest caries risk condition.

3 . Dentobuff strip detection materials

In this test, pipettes for drawing up saliva, detective paper and standard map were used. The buffer capacity of saliva was expressed as follows: Degree 1, yellow, $\mathrm{pH} \leqq 4.0$; Degree 2, green, $\mathrm{pH} 4.5-5.5$; and Degree 3, dark-blue, $\mathrm{pH}$ $\geqq 6.0$. Degree 3 means the highest buffer capacity or lowest caries activity.

Dentocult LB and Dentobuff strip materials were from Orion Diagnostica, Finland.

II. Methods

1. Dental examination

The examiners and recorders were selected and fixed throughout the study. Type TK dental chair and cold light source (Yoshida, Japan) were used for dental examination. The grades of caries were commented as follows: 0 , no caries; 0.5 , filled tooth; 1 , secondary caries, enamel caries or dentin caries; and 2, pulp exposed deep caries, remaining root.

2. SCAT detection

Three times of scrubbing on buccal cervical one third region of $\underline{E}+\underline{E}$ with a sterilized cotton swab were made for each examined child. The swab was inserted into a test tube containing SCAT reagent and mixed for 1 min on a vortex. The test tubes were incubated at $37{ }^{\circ} \mathrm{C}$ for $48 \mathrm{hr}$ in type III incubator (Sankin, Japan). The color of SCAT reagent was checked and the caries activity was determined by comparing with the standards. The children were examined at 2:00 pm without eating, oral cavity cleaning or tooth brushing for more than two hours.

3. Dentocult $\mathrm{LB}$ and Dentobuff strip tests

The special paraffin was chewed for $5 \mathrm{~min}$ by each examined child. Then 3 to $5 \mathrm{ml}$ saliva was collected and both the two tests were performed by specialists respectively.

1) Dentocult LB test

Saliva was poured slowly on both sides of the medium layer and incubated at $37{ }^{\circ} \mathrm{C}$ for 96 hr. The number and the density of bacterial colonies were checked and the degrees were determined by comparing with the standards.

2 ) Dentobuff strip test

After piping saliva on the test paper to cover the yellow area for $5 \mathrm{~min}$, the color changing was checked and the Dentobuff strip degrees were determined by comparing with standards.

The two tests were performed at 10:00 am and the examined children were without eating, oral cavity cleaning or tooth brushing for more than two hours. 


\section{Statistics}

CSI (Caries Severity Index) was calculated as follows:

$$
\mathrm{CSI}=\frac{\text { Total grades of caries }}{\text { Total number of teeth } \times 2} \times 100
$$

The data were analyzed by $X^{2}$, ANOVA and SNK method. Correlation coefficients between the factors were also calculated.

III. Examining children

398 two to six-year-old children from the kindergarten of Shanghai Medical University were examined randomly for caries status and SCAT detection. For comparison of the tests, 96 two to six-year-old children were examined randomly for caries status, SCAT, Dentocult LB and Dentobuff strip tests.

\section{Results}

I. Caries incidence and SCAT detections for children

1. Caries incidence of children

The caries incidence of 398 children is shown in Table 2. Among 2 to 6-year-old children, the caries prevalence, $\mathrm{dft}$ and CSI rapidly increased with age up to 5 while their increment

Table 2 Caries incidence in 398 preschooling children

\begin{tabular}{|c|c|c|c|c|c|c|c|c|}
\hline \multirow{2}{*}{ Age } & \multirow{2}{*}{ Sex } & \multirow{2}{*}{$\begin{array}{l}\text { Number } \\
\text { of } \\
\text { children }\end{array}$} & \multicolumn{2}{|c|}{ Caries prevalence } & \multicolumn{2}{|c|}{$\mathrm{dft}$} & \multicolumn{2}{|c|}{ CSI } \\
\hline & & & Number & $\%$ & Examinees & Sufferers & Examinees & Sufferers \\
\hline \multirow{3}{*}{2} & Male & 25 & 3 & 12.00 & $0.28 \pm 0.16$ & $2.33 \pm 0.33$ & $0.77 \pm 0.43$ & $6.44 \pm 0.57$ \\
\hline & Female & 24 & 5 & 20.83 & $0.33 \pm 0.18$ & $1.60 \pm 0.60$ & $0.86 \pm 0.45$ & $4.14 \pm 1.47$ \\
\hline & Subtotal & 49 & 8 & 16.33 & $0.31 \pm 0.13$ & $1.87 \pm 0.40$ & $0.82 \pm 0.31$ & $5.00 \pm 0.99$ \\
\hline \multirow{3}{*}{3} & Male & 42 & 15 & 35.71 & $1.10 \pm 0.28$ & $3.07 \pm 0.48$ & $2.98 \pm 0.82$ & $8.33 \pm 1.52$ \\
\hline & Female & 31 & 13 & 41.94 & $2.23 \pm 0.79$ & $5.31 \pm 1.53$ & $6.72 \pm 2.64$ & $16.03 \pm 5.40$ \\
\hline & Subtotal & 73 & 28 & 38.36 & $1.58 \pm 0.37$ & $4.11 \pm 0.77$ & $4.57 \pm 1.23$ & $11.91 \pm 2.68$ \\
\hline \multirow{3}{*}{4} & Male & 59 & 34 & 57.63 & $2.68 \pm 0.46$ & $4.65 \pm 0.62$ & $7.63 \pm 1.47$ & $13.24 \pm 2.08$ \\
\hline & Female & 58 & 34 & 58.62 & $2.67 \pm 0.50$ & $4.56 \pm 0.68$ & $8.13 \pm 1.68$ & $13.86 \pm 2.43$ \\
\hline & Subtotal & 117 & 68 & 58.12 & $2.68 \pm 0.34$ & $4.60 \pm 0.46$ & $7.88 \pm 1.11$ & $13.55 \pm 1.59$ \\
\hline \multirow{3}{*}{5} & Male & 65 & 46 & 70.77 & $3.32 \pm 0.40$ & $4.70 \pm 0.43$ & $9.97 \pm 1.33$ & $14.09 \pm 1.50$ \\
\hline & Female & 58 & 38 & 65.52 & $3.41 \pm 0.50$ & $5.21 \pm 0.59$ & $9.26 \pm 1.54$ & $14.14 \pm 1.92$ \\
\hline & Subtotal & 123 & 84 & 68.29 & $3.37 \pm 0.32$ & $4.93 \pm 0.35$ & $9.64 \pm 1.00$ & $14.11 \pm 1.19$ \\
\hline \multirow{6}{*}{6} & Male & 18 & 14 & 72.22 & $2.94 \pm 0.65$ & $3.79 \pm 0.69$ & $7.92 \pm 2.11$ & $10.19 \pm 2.39$ \\
\hline & Female & 18 & 13 & 77.78 & $4.50 \pm 1.07$ & $6.23 \pm 1.16$ & $11.65 \pm 3.03$ & $16.13 \pm 3.45$ \\
\hline & Subtotal & 36 & 27 & 75.00 & $3.72 \pm 0.63$ & $4.96 \pm 0.69$ & $9.79 \pm 1.84$ & $13.05 \pm 2.11$ \\
\hline & Male & 209 & 112 & 52.11 & $2.30 \pm 0.21$ & $4.29 \pm 0.28$ & $6.63 \pm 0.67$ & $12.37 \pm 0.97$ \\
\hline & Female & 189 & 103 & 52.97 & $2.70 \pm 0.28$ & $4.96 \pm 0.40$ & $7.66 \pm 0.89$ & $14.05 \pm 1.34$ \\
\hline & Total & 398 & 215 & 52.52 & $2.49 \pm 0.17$ & $4.61 \pm 0.24$ & $7.12 \pm 0.55$ & $13.18 \pm 0.82$ \\
\hline
\end{tabular}


Table 3 Caries incidence under different SCAT degrees

\begin{tabular}{|c|c|c|c|c|c|c|c|c|}
\hline \multirow{2}{*}{$\begin{array}{l}\text { SCAT } \\
\text { degree }\end{array}$} & \multirow{2}{*}{ Sex } & \multirow{2}{*}{$\begin{array}{l}\text { Number } \\
\text { of } \\
\text { children }\end{array}$} & \multicolumn{2}{|c|}{ Caries prevalence } & \multicolumn{2}{|c|}{$\mathrm{dft}$} & \multicolumn{2}{|c|}{ CSI } \\
\hline & & & Number & $\%$ & Examinees & Sufferers & Examinees & Sufferers \\
\hline \multirow{3}{*}{0} & Male & 81 & 34 & 41.98 & $1.32 \pm 0.24$ & $3.15 \pm 0.41$ & $3.37 \pm 0.76$ & $8.02 \pm 1.47$ \\
\hline & Female & 67 & 33 & 49.25 & $1.63 \pm 0.30$ & $3.30 \pm 0.45$ & $4.22 \pm 0.87$ & $8.56 \pm 1.41$ \\
\hline & Subtotal & 148 & 67 & 45.27 & $1.46 \pm 0.19$ & $3.22 \pm 0.30$ & $3.75 \pm 0.57$ & $8.29 \pm 1.01$ \\
\hline \multirow{3}{*}{1} & Male & 73 & 35 & 47.95 & $2.18 \pm 0.38$ & $4.54 \pm 0.57$ & $6.31 \pm 1.20$ & $13.16 \pm 1.91$ \\
\hline & Female & 69 & 27 & 39.13 & $1.62 \pm 0.41$ & $4.15 \pm 0.85$ & $4.86 \pm 1.47$ & $12.43 \pm 3.30$ \\
\hline & Subtotal & 142 & 62 & 43.66 & $1.91 \pm 0.28$ & $4.37 \pm 0.49$ & $5.61 \pm 0.94$ & $12.48 \pm 1.78$ \\
\hline \multirow{3}{*}{2} & Male & 33 & 24 & 72.73 & $3.85 \pm 0.61$ & $5.29 \pm 0.62$ & $11.31 \pm 1.83$ & $15.54 \pm 1.87$ \\
\hline & Female & 34 & 26 & 76.47 & $4.76 \pm 0.83$ & $6.23 \pm 0.90$ & $14.13 \pm 2.63$ & $18.48 \pm 2.95$ \\
\hline & Subtotal & 67 & 50 & 74.63 & $4.31 \pm 0.52$ & $5.78 \pm 0.55$ & $12.74 \pm 1.61$ & $17.07 \pm 1.78$ \\
\hline \multirow{3}{*}{3} & Male & 22 & 19 & 86.36 & $3.95 \pm 0.63$ & $4.58 \pm 0.61$ & $12.69 \pm 2.29$ & $14.69 \pm 2.34$ \\
\hline & Female & 19 & 17 & 89.47 & $6.74 \pm 0.88$ & $7.53 \pm 0.77$ & $18.35 \pm 2.37$ & $20.51 \pm 2.08$ \\
\hline & Subtotal & 41 & 36 & 87.80 & $5.24 \pm 0.57$ & $5.97 \pm 0.54$ & $15.31 \pm 1.69$ & $17.44 \pm 1.63$ \\
\hline
\end{tabular}

became small and CSI of cases rather decreased in 6-year-old children. There were no significant differences between male and female in caries prevalence $(p=0.86)$, dft and CSI of examinees or of sufferers $(\mathrm{p}=0.24,0.35,0.16,0.30$, respectively).

2 . Caries incidence classified by SCAT degree

Table 3 shows the caries incidence of 398 children classified by different SCAT degrees. Significant differences were found among caries prevalences of different SCAT degrees $(p=$ 0.001). There were highly significant differences in $\mathrm{dft}(\mathrm{p}=0.0001)$ and CSI $(\mathrm{p}=0.0001)$ for different SCAT degrees of examinees. The SNK method distinctly showed significant differences in dft or CSI of examinees between Degree 0 and 2 or 3 and between Degree 1 and 2 or 3 . There were also significant differences in $\mathrm{dft}(\mathrm{p}=0.0001)$ and CSI $(\mathrm{p}=0.0001)$ for different SCAT degrees of sufferer. The SNK method revealed distinct differences between Degree 0 and 1,2 or 3 in $\mathrm{dft}$ and between Degree 0 and 2 or 3 and between Degree 1 and 2 or 3 in CSI of sufferer.

3. Correlation between SCAT degree and caries incidence

The results of SCAT showed close correlations with caries prevalence $(r=0.26, p=0.0001)$, dft of examinees and sufferers $(r=0.34, p=0.0001$, for both), and CSI of examinees and sufferers $(\mathrm{r}=0.35, \mathrm{p}=0.0001$, and $\mathrm{r}=0.38, \mathrm{p}=0.0001$, respectively).

II. Comparison between the three caries activity tests

Figs. 1 to 3 show the results of linear regression analyses for dft and CSI versus SCAT degree, Dentocult LB degree and Dentobuff strip degree, respectively, for 96 three to six-yearold children. Both of $\mathrm{dft}$ and CSI showed significant linear correlations with SCAT degree ( $p$ $=0.005, \mathrm{p}=0.006$ ). In Dentocult LB test, similar increases in mean values of $\mathrm{dft}$ and CSI with increased degree were found as in SCAT although the standard deviations were extremely 


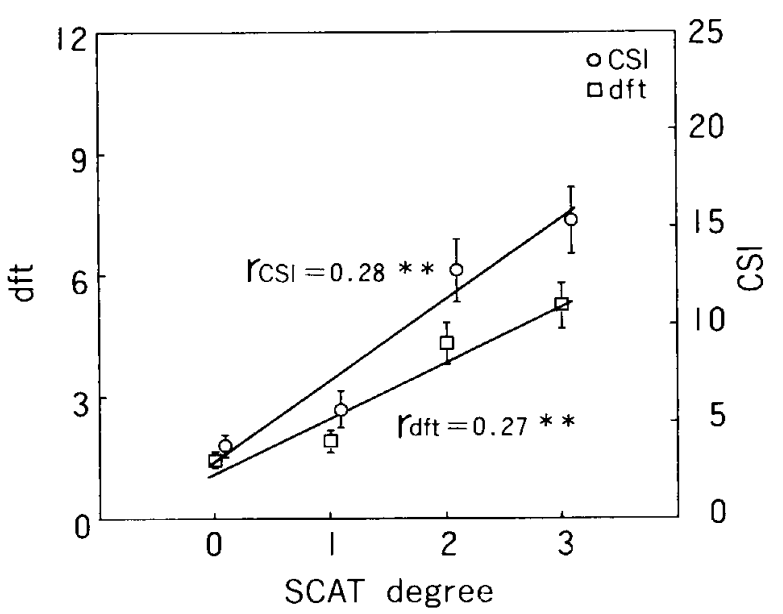

Fig. 1 Distribution of $\mathrm{dft}$ or $\mathrm{CSI}$ in relation to SCAT degree. Positive correlation existed between SCAT degree and dft or CSI.

large. The linearity between $\mathrm{dft}$ and the degree was significant $(p=0.026)$ but not between CSI and the degree $(\mathrm{p}=0.066)$. There was no significant linear correlation between $\mathrm{dft}$ or CSI and Dentobuff strip degree $(p=0.405$ or 0.440$)$.

\section{Discussion}

I . The significance of caries activity detection

The caries activity indicates the sensitivity of the examinee to caries. The more active the reaction in the test, the higher the caries prevalence $^{810)}$. The caries activity is usually detected from saliva or dental plaque, and the prevention and treatment plan can be made scientifically according to the test results. In order to utilize the test effectively and economically, it should be performed in kindergartens and primary schools and adequate prevention and/or treatment plans should be made for children grouped by different levels of activity. It is essential, therefore, to get understanding and cooperation of the parents.

Recently such works have been more developed and much progress was made in the prevention and treatment of caries. Anyhow, the caries status has not been improved. The caries prevalence and caries are still high in children. In 1995, the caries prevalence of primary teeth in five-year-old children was $76.55 \%$ in China $(75.69 \%$ in cities, $78.28 \%$ in rural area). The dft was 4.48 (4.32 in cities, 4.80 in rural area). Compared with those in 
1980 's, the caries incidence of primary teeth in children has changed. Higher caries prevalence is in rural area instead of cities ${ }^{11,12)}$.

In this study, the caries prevalence was $68.29 \%$ and $\mathrm{dft}$ was 3.37 in five-year-old children and $52.52 \%$ and 3.86 in two to six-year-old children, respectively, which are lower than those in 1980's and early 1990's in Shanghai, and also lower than those in China in 1995 ${ }^{11,13,14)}$. The better results in this study may be related to the examined children from the kindergarten with dental health care room and health education work for six years. The caries prevalence and $\mathrm{dft}$ or CSI in six-year-old children group were not always higher than those in five-year-old children group. It may be due to the increased shedding of primary teeth and treatment of the caries in the former as described in the literatures ${ }^{15,16)}$.

Facing with the severe caries status in more than three hundred million children ${ }^{17)}$ and with the small number of dentists, especially pediatric dentists against the big population in China, the newly developed SCAT has its scientific, social and economic extension and significance in the prevention and treatment of caries as an economic, simple and sensitive method for detecting caries activity.

II. Characteristics of SCAT

The examination by SCAT is based on the acid-producing ability of dental plaque. During incubation the growth of bacteria dissociates sucrose into lactic acid, which reacts with the indicator and results in the color changes. The amount of bacteria and caries activity was determined according to lactic acid produced. The main composition and selected principles of SCAT reagent are as follows:

1. Selection of carbon source

Sufficient carbon is necessary for caries-induced bacteria. When compared with glucose, sucrose which is commonly used in our life has bigger molecular weight and is less inhibitory to the growth of microorganisms according to its lower osmotic pressure. As one kind of disaccharides it is more used by caries-induced bacteria than monosaccharide and will exclude the growth of other bacteria using monosaccharide only. The selection of sucrose will therefore make the test more accurate ${ }^{18,19)}$.

The concentration of sucrose is also important. With less than $1 \%$ sucrose the cariesinduced bacteria could not get enough carbon for growing and no color reactions appeared because of lack of lactic acid. More than $40 \%$ sucrose, under high osmotic pressure circumstance on the other hand, inhibited the metabolism of bacteria and led them to die, especially for the caries-induced bacteria and Gram's positive bacteria. Also under high temperature without bacteria, high concentration of sucrose reacted with amino acid from peptone and caused brown color, which resulted in the increase of pigment and the decrease of nutrient elements. From the experiments with various concentrations of sucrose, we found that $10 \%$ was the best. Under this condition, there will not any increase of pigment and the color reaction will not be delayed.

2. Selection of nitrogen source

Nitrogen is also necessary for growth of bacteria. Tryptose was selected as the source of 
nitrogen in SCAT reagent. The concentration of tryptose is also important. If it is less than $0.1 \%$, caries-induced bacteria can not get enough nitrogen for growing and the detection may lead to mistake. When it exceeds $5 \%$, the balance between carbon and nitrogen will be broken and metabolism will be disrupted ${ }^{18)}$. The use of $\mathrm{NaN}_{3}$ inhibited the growth of Gram's negative bacteria in SCAT reagent and it will save more nitrogen.

The detection method is an acid producing fermented culture. The main element in produced organic acid is carbon with no or little nitrogen. Usually the bacteria need more carbon and less nitrogen and the ideal ratio of carbon to nitrogen is $100: 0.2-2.0^{200}$. In SCAT reagent, therefore, the concentration of tryptose was selected as $1 \%$ because it almost satisfied the ideal ratio. As comparing with the expensive tryptose used abroad, the native tryptose produced in China is cheaper and good enough for use.

3. The use of $\mathrm{NaN}_{3}$

$\mathrm{NaN}_{3}$ is an inhibitor for the growth of microorganisms by restricting biologic respiration. It shows different effects on different kinds of bacteria. The growth of Gram's negative bacteria is more strongly inhibited than that of Gram's positive one ${ }^{18,21}$. We took advantage of this feature, using $\mathrm{NaN}_{3}$ in SCAT reagent to inhibit the growth of non-caries-induced bacteria such as Gram's negative bacteria effectively and to less inhibit the growth of Gram's positive bacteria such as Streptococci mutans or Lactobacilli for decreasing the unfavorable influence on the test.

The concentration of $\mathrm{NaN}_{3}$ is also important. The optimum concentration for good detection with this test was $0.02 \% \mathrm{NaN}_{3}$, which preferably inhibited the growth of most of the non-caries-induced bacteria. At this concentration $\mathrm{NaN}_{3}$ will not affect the color reaction of bromocresol green and reaction rate can be controlled to ensure the accuracy of the test.

4. Indicators

We used two color indicators, bromocresol green and bromocresol purple here to avoid the color concentration on the top of the cotton swab when bromocresol green was employed alone. By adding $0.0015 \%$ bromocresol green and $0.003 \%$ bromocresol purple, the color reaction occurred homogeneously and the change was easily and clearly evaluated.

III. The application of SCAT detection

1. Caries incidence

The analyses of the caries incidence for different degrees of SCAT showed highly significant differences in caries prevalence, $\mathrm{dft}$ and CSI of examinee or sufferer. There was also high close correlation between SCAT degrees and caries prevalence, dft or CSI, indicating that SCAT could be a good measure of the caries status and its severity and caries sensitivity.

The similarity of SCAT and Cariostat method used for detecting caries activity is that both of them detect the capability of producing acid from dental plaque to determine the caries sensitivity of the host ${ }^{22,23)}$. Tsubouchi et al. (1994) ${ }^{24)}$ examined 637 eighteen-month-old children with Cariostat method and found the correlation between the results and caries incidence, and the children with high caries risk could be determined. Koroluk et al. (1994) ${ }^{25)}$ 
gave dental examination and Cariostat test for 153 three to five-year-old children and found that there was significant difference between Cariostat degrees in $\mathrm{dft}$, dfs or CSI. It was shown from these references that the detection of capability of producing acid from dental plaque could well represent the caries sensitivity of the host indeed.

The author previously detected the caries activity for 391 three to five-year-old children with Cariostat method and analyzed if the amount of sample had any effect on the results, and revealed that there was highly significant correlation between the results and caries prevalence, dft or CSI, and sample amount did not affect the results ${ }^{26}$. It means that no attention needs to be paid to sample amount in SCAT detection.

2. Comparisons among SCAT, Dentocult LB and Dentobuff strip detections

Dentocult LB and Dentobuff strip tests are new methods for detecting caries activity by examining the amount of Lactobacilli in saliva in the former and the buffering capability of saliva against acid in the latter.

Among the bacteria related to caries, Streptococcus mutans is considered to be the most active caries inducer. Fitzgerald et al. $(1966)^{27)}$ thought that there was no direct relation between Lactobacilli and caries, and not a few reports stressed that Lactobacilli could indirectly participate in caries mainly induced by Streptococcus mutans ${ }^{28)}$. Oshikane $(1970)^{29)}$ indicated that during $\mathrm{pH} 4.5-5.0$ of saliva both Streptococcus mutans and Lactobacilli were active while only Lactobacilli could be active under $\mathrm{pH} 4.0$. The method for detecting the capability of producing acid by Lactobacilli for confirming caries activity of the host is still progressing now. The author ${ }^{30)}$ detected the amount of Lactobacilli in saliva with Dentocult LB test in 164 three to five-year-old children and found that there were close correlation between the amount of Lactobacilli and caries prevalence of primary teeth, dft or CSI and that the amount of Lactobacilli could reflect the caries incidence of primary teeth.

In this study, it was shown that $\mathrm{dft}$ and CSI significantly increased with larger Dentocult LB degrees. Enomoto $(1994)^{8)}$ also reported that the larger the Dentocult LB degree, the more the number of the caries surfaces. The results of Dentobuff strip test in this study, on the other hand, showed neither significant difference nor significant correlation between caries prevalence, dft or CSI and Dentobuff strip degree. Tahara (1995) ${ }^{22)}$ found in 210 six-month to six-year-old children that there was no difference in dfs between different Dentobuff strip degrees. Enomoto $(1994)^{8)}$ reported that there was correlation between caries incidence of permanent teeth but not of primary teeth and Dentobuff strip degree. Saliva buffer is often affected by secreting amount, varying with collecting time and method. It may be one of the reasons why the results of this test could not be well related to the caries incidence. Such disadvantages with the use of saliva may also occasionally cause unstable results in Dentocult LB test as seen in the larger standard deviations of the caries incidence classified for each degree.

The results of SCAT were well correlated with the caries activity of the host, almost parallel to those of Dentocult LB test. Judging from the statistical $p$ value and correlation coefficient, however, the linear relationship between the test results and the real $\mathrm{dft}$ or CSI 
rather appeared more distinct in SCAT than in Dentocult LB test.

In consideration of the severe caries status and lack of professional dentists in China, it is practical and significant to detect caries activity of the children for prevention and earlier treatment of caries. In addition to the usefulness of the results, the newly developed SCAT detection is simple and inexpensive to operate and it is expected to come into wide use.

\section{Conclusion}

The present study evaluated the utility of a new caries activity test named SCAT (Shanghai Tiedao University Caries Activity Test) for predicting the caries incidence of primary teeth. The caries activities of 398 preschooling children were classified into 4 degrees according to the color changes of SCAT reagent in association with the capability of producing acid from dental plaque. The conventional Dentocult LB and Dentobuff strip tests were also performed for comparison. Their results were then compared with the real caries status of the children obtained by stomatic examination.

Highly significant differences in caries prevalence, dft and CSI were found between different SCAT degrees with significant positive correlations. The results of SCAT showed almost parallel relationship with those of Dentocult LB test. No significant correlation between Dentobuff strip test and stomatic examination was recognized in this study.

Together with the advantages of SCAT such as simple operation and low cost, foregoing results suggest that SCAT may be an excellent measure of caries incidence of primary teeth for earlier prediction, prevention and treatment of caries.

\section{Acknowledgement}

The author is deeply indebted to Prof. Choji Uchiyama for his invaluable advice and discussions throughout this investigation and also wishes to express great gratitude to Prof. Yoshio Kozono and Dr. Ker-Kong Chen, Kyushu Dental College, for their constant support. The author also expresses deep thanks to Mr. Si-You Shi, Ms. Lian-Yuan Chen, Ms. Qin Liang and Ms. Li Wei, Shanghai Tiedao University, for their assistance in this resaerch work.

\section{References}

1) Nakagaki, H.: Caries activity test. In: Manual of oral health activity. 1st ed. Ishiyaku Publishers, Inc., Tokyo, 1987, 69-78.

2) Bratthall, D.: A practical guide to the assessment of caries risk: Yanagisawa, I., Suzuki, A. and Maki, S. Translated into Japanese, 1st ed. Eiko Corporation, Tokyo, 1994.

3 ) Morikawa, K., Kurumada, F., Hashimoto, N., Ui, H., Watanuki, K. and Eto, M.: Diet guidance at the conservation dentistry of Tohoku Dental University Hospital (1) Oral findings and the caries activity tests. J. Tohoku Dent. Univ. 13: 88-94, 1986.

4) Suzuki, S., Watanabe, K., Fujino, T., Nakamukai, M., Ozawa, Y. and Ikezaki, R.: Oral status and caries activity of dental hygienist students bull. Shohnan Jun. College, 2: 55-58, 1991.

5 ) Okazaki, Y.: Understandings of the oral health instruction-Various utilizations of Cariostat-Dent. Hygienist 16: 44-53, 1992.

6 ) Kadono, T., Enomoto, T., Taniuchi, H., Tsurutani, M. and Mikami, M.: The present aspect of 
Cariostat-Consideration from the screening test of Cariostat. Dent. Hygienist 14: 807-812, 1994.

7 ) Ohgawara, S.: Utilization of Cariostat on dental health check-up of infants. J. Jpn. Assoc. Dent. Hygienist 16: 59-64, 1998.

$8)$ Shimono, T., Mizuno, J., Nonomura, E., Morisaki, I., Masuda, N., Matsumura, S. and Sobue, S.: Studies on the new caries activity test (Cariostat) - Comparisons to the synder test. Jpn. J. Ped. Dent. 14: 6-18. 1976.

$9)$ Shi, S. Z., Chen, W. J., Nakata, M., Futatsuki, T., Ogata, T. and Hamada, S.: The comparison of the caries status in 3-year -old children and the maternal child caries activities between Chinese and Japanese. Chinese J. Stomatology 26:306-608, 1991.

10) Enomoto, C.: Epidemiological study on effectiveness of caries activity tests and on prevalence of cariogenic bacteria in 4 to 19-year-old people. J. Kyushu Dent. Soc. 48: 414-425, 1994.

11) The epidemiology sampling survey of dental caries and periodontal disease in students: The Ministry of Public Health, People's Republic of China. People's Health Publishing Co., 1st ed. Beijing, 1987, 27.

12) The second national epidemiological investigation of oral health: The technical guiding team of the second national epidemiological investigation of oral health, Beijing, 1998, 19.

13) Shi, S. Z., Ding, Y. Z. and Xu, S. X.: Survey of Caries incidence among 15,054 children in Shanghai. Stomatology 8: 10-13, 1983.

14) Shi, S. Z., Morioka, T., Zhao, Y. M., Wang, S. and Chen, G. Z.: The investigation and analysis of congenital abnormalities in deciduous teeth of 10,804 preschool children. Stomatology 12: 169-171, 1992.

15) Hayashi, Y., Yakushiji, M., Machida, Y., Shi, S. Z., Shan, W., Jiang, L. and Liang Q.: Oral health status of Chinese children in Shanghai. Shika Gakuho, 96:577-584, 1996.

16) Hayashi, Y., Tsujiguchi, A., Yakushiji, M., Machida, Y., Shi, S. Z., Jiang, L. and Liang Q.: Black stains and caries in the deciduous dentition of Shanghai kindergarten children. Shika Gakuho, 97 : 441-447, 1997.

17) Editional Committee of Year Book of Chinese Stomatology.: Year Book of Chinese Stomatology: Sichuan Science and Technology Publishing Co., 1st ed. Shendu, 1997, 20.

18) Wuxi Light Industry Institute, Tianjing Light Industry Institute, Huamam Industry Institute, and Dalian Light Industry Institute: Microbiology, Light Industry Publishing Co., 1st ed. Beijing, 1980, 9.

19) Wuxi Light Industry Institute, Tianjing Light Industry Institute, Huamam Industry Institute, and Dalian Light Industry Institute: Food Microbiology, Light Industry Publishing Co., 1st ed. Beijing, 1985, 10.

20) Qian, C. R. and Dong B. H.: Basic knowledge and experiment guiding of Microbiology. Science Publisher Inc., 1st ed. Beijing, 1979, 1.

21) Chen, G. T., Li, L. G., Zhang Q. X. and Fan, H. Y. (translated): The experimental method of Microbiology in Microbiology Research Symposium. Science Publisher Inc., 1st ed. Beijing, 1983, 5.

22) Uchikura, Y., Tosaka, S., Takahashi, K. and Okumura, T.: On the caries activity test Part 1 Comparisons of MSBB test, Cariostat and RD test. Shigaku, 77:682-693, 1989.

23) Tahara, A.: Perspective longitudinal cohort study on prediction of caries risk using caries activity tests in 0- to 6-year old children. J. Kyushu Dent. Soc. 49: 184-195, 1995.

24) Tsubouchi, J., Higashi, T., Shimono, T., Domoto, P. K. and Weinstein, P.: A study of baby bottle tooth decay and risk factors for 18-month old infants in rural Japan. J. Dent. Child. 61: 293-298, 1994.

25) Koroluk, L., Hoover, J. N. and Komiyama, K.: The sensitivity and specificity of a colorimetric microbiological caries activity test (Cariostat) in preschool children. Pediatr. Dent. 16:276-281, 1994. 
26) Shi, S. Z., Chen, L. Y. and Shimono, T.: The study of relationship between sampling measure and research result with Cariostat. Stomatology, 17: 169-171, 1997.

27) Fitzgerald, R. J. Jordan, H. V. and Archard, H. O.: Dental caries in gnotobiotic rats infected with a variety of Lactobacillus acidophilus. Archs. Oral Biol. 11: 473-476, 1996.

28) Kawano, T., Sugiyama, Y., Matsuo, T., Masaki, H., Okudera, G., Kimoto, S., Kaneko, N., Shikatani, M., Kinoshita, F., et al.: Caries activity test by streptococcus mutans Part 1 On the relations of caries status. J. Dent. H1th. 33: 6-17, 1983.

29) Oshikane, A.: Dental Biochemistry. 1st ed. Ishiyaku Publishers Inc., Tokyo, 1970, 471-473.

30) Shi, S. Z., Zhao, Y. M., Hayashih, Y. Yakushiji, M. and Machida, Y.: The relationship between caries activity and caries status in primary teeth-The application of Dentocult LB method. West China J. Stomatology, 1998 (in press).

\title{
新しい齬蝕活動性試験法の有用性
}

\author{
石筬 \\ 上海鉄道大学口腔医学院小児歯科学講座（主任：石 四筬教授） \\ 九州歯科大学口腔細菌学講座 (指導 : 内山長司教授)
}

平成 10 年 8 月 25 日受理

雟蝕罹患率の減少や予防のために様々な研究が行われ ている，㯨蝕活動性試験はその中の一つであり，現在は

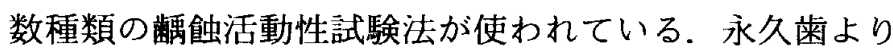
あ乳㐘の時点から着手することが最あ有効な手段である が，いずれの方法も高価なものであるから，広範囲（特 に中国の場合）に普及することが困難だと思われる。そ のため, 上海鉄道大学式辆蝕活動性試験（以下 SCAT 之 略）という新しい酮蝕活動性試験方法を開発した。本研 究は, この試験法の乳歯龋蝕状況を予測する手段として の有用性を調べたものである.SCAT は雬垢からの酸生 成能に上る試薬の変色を利用し, 標準色溶液との比較加

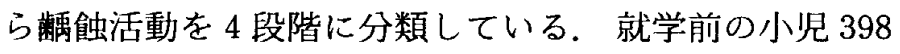
名について SCATによる試験を行い，その結果を口腔 内診査から得られた稱蝕状況之対比し, 検討を加えた。
また, 従来からある Dentocult LB 試験および Dentobuff strip 試験屯同時に行い，これらの結果と兓蝕状況 との関連についても比較検討した。

4 段階の SCAT 楀蝕活動度の間で, 禹蝕罹患率, $\mathrm{dft}$ および CSI（㯨蝕重度指数）に高度な有意差がみられ， 䩹蝕活動度と各々の間には正の相関が認められた。本研 究の結果では, Dentocult LB 試験では口腔内診查と一 部に相関がみられたが，Dentobuff strip 試験では相関 は認められず, SCAT 暗蝕活動度が楀蝕状況と最も密接 な関連性を示した。

以上の結果は, SCAT が乳雬の歶蝕䍜患を予測できる すぐれた手段であることを示しており，操作が容易であ ること, 経済的であることなどの利点とと屯に有用な試 験方法であることを示唆している. 